\title{
Populasi Mikroorganisme Tanah pada Lahan Jagung setelah Aplikasi Pupuk Poliakrilat
}

\section{(Soil Microorganism Population in Corn Fields upon Application of Polyacrylate Fertilizers)}

\author{
Almi Abdila, Nurjannah Japarang, Nur Agustin, Warida Hafni, Alfiqi Dwiva Annisi, Hilda Karim, Andi \\ Asmawati Azis, Muhammad Junda, Oslan Jumadi ${ }^{\star}$
}

(Diterima Desember 2020/Disetujui Desember 2021)

\begin{abstract}
ABSTRAK
Jumlah dan jenis mikroorganisme dalam tanah mengindikasikan kesuburan tanah. Penggunaan pupuk dapat memengaruhi pertumbuhan populasi mikroorganisme dalam tanah. Uji kuantitatif dilakukan untuk mengevaluasi bagaimana pengaruh penggunaan pupuk pada keberadaan bakteri, jamur, dan alga. Jumlah bakteri dan jamur dihitung menggunakan metode standard plate count, sedangkan jumlah alga dihitung menggunakan metode most probable number. Jumlah bakteri terbanyak ditemukan pada aplikasi urea-fosfat-kalium (UPK) polimer zeolit $50 \%$, yaitu 3,4 $\times 10^{6} \mathrm{CFU} / \mathrm{mL}$, jamur terbanyak ditemukan pada aplikasi $25 \%$, yakni $2,5 \times 10^{4} \mathrm{CFU} / \mathrm{mL}$, sedangkan alga terbanyak ditemukan pada tanah kontrol, $2,7 \times 10^{4} \mathrm{CFU} / \mathrm{mL}$. Akan tetapi untuk perlakuan, jumlah terbanyak ditemukan pada pemberian UPK polimer zeolit $50 \%$ sebanyak $1,4 \times 10^{3} \mathrm{CFU} / \mathrm{mL}$ sehingga dapat disimpulkan bahwa pemberian UPK polimer zeolite memengaruhi jumlah mikroorganisme pada lahan jagung.
\end{abstract}

Kata kunci: mikroorganisme tanah, poliakrilat, UPK, zeolit

\section{ABSTRACT}

The number and type of microorganisms in the soil indicate soil fertility. The use of fertilizers can affect the growth of microorganisms in the soil. Quantitative tests are conducted to evaluate how fertilizers affect the presence of bacteria, fungi, and algae. The number of bacteria and fungi is calculated using the standard plate count method, while the number of algae is calculated using the most probable number method. The highest number of bacteria found in urea-phosphate-potassium (UPK) applications of zeolite polymers is $50 \%$, which is $3.4 \times 10^{6} \mathrm{CFU} / \mathrm{mL}$; the most fungi are found in $25 \%$ of applications, which is $2.5 \times 10^{4} \mathrm{CFU} / \mathrm{mL}$. In contrast, the highest algae population was in control soils, $2.7 \times 10^{4} \mathrm{CFU} / \mathrm{mL}$. However, for treatment, an enormous amount is found in the administration of $50 \%$ zeolite polymer UPK as much as $1.4 \times 10^{3} \mathrm{CFU} / \mathrm{mL}$, so it can be concluded that the administration of UPK zeolite polymer affects the number of microorganisms on the cornfield.

Keywords: soil microorganism, polyacrylate, UPK, zeolite

\section{PENDAHULUAN}

Jagung merupakan komoditas pertanian yang berperan penting dalam perekonomian nasional setelah beras. Oleh karena itu, agar produksi jagung dapat tetap stabil, maka lahan jagung perlu diberi perhatian khusus agar tetap produktif. Keberadaan mikroorganisme khususnya mikroorganisme tanah sangat melimpah. Peran mikroorganisme ini sangat besar pada kesuburan tanah terlebih lagi sangat bermanfaat bagi pertumbuhan tanaman yang ada di sekitarnya. Menurut Irfan (2014), kelimpahan jumlah dan jenis mikroorganisme tanah dapat mengindikasikan kesuburan tanah, disertai dengan kecukupan bahan organik dalam tanah, kesesuaian suhu tanah, dan kecukupan air, serta kesesuaian kondisi ekologi tanah.

Jurusan Biologi, Fakultas Matematika dan IImu Pengetahuan Alam, Universitas Negeri Makassar, Jl. Daeng Tata Raya, Makassar 90224

*Penulis Korespondensi: Email: oslanj@unm.ac.id
Biomassa mikroorganisme tanah kurang dari $5 \%$ bahan organik dalam tanah, meski berperan dalam setidaknya tiga fungsi penting di tanah dan lingkungan. Mikroorganisme ini merupakan sumber karbon, nitrogen, fosforus, dan belerang yang labil; penyerap karbon, nitrogen, fosforus, dan sulfur secara langsung; dan agen transformasi nutrisi dan degradasi pestisida. Selain itu, mikroorganisme membentuk asosiasi simbiotik dengan akar, bertindak sebagai agen hayati terhadap patogen tanaman, berkontribusi dalam agregasi tanah, dan berpartisipasi dalam pembentukan tanah (Dalal 1998).

Poliakrilat memiliki sifat superabsorben sehingga mampu mengembang dalam air. Tidak berbeda dengan superabsorben lainnya, polimer ini juga degradabel. Poliakrilat dapat menyebabkan laju pelarutan urea semakin lambat dengan memberi penghalang fisik berupa lapisan pelindung pada urea (Yenni et al. 2012).

Mikroorganisme tanah diuji secara kuantitatif untuk mengukur bagaimana pengaruh aplikasi pada keberadaan mikroorganisme tanah. Uji kuantitatif pada 
penelitian ini ditinjau dari keberadaan bakteri, jamur, dan alga. Optimisasi pemanfaatan pupuk oleh tanaman sangat dipengaruhi oleh keberadaan mikroorganisme tanah. Metode pendekatan ini diharapkan dapat digunakan untuk menduga jumlah mikroorganisme tanah sehingga diketahui kelimpahannya pada lahan dan untuk mengevaluasi pengaruh polialkrilat pada kelimpahan mikroorganisme, khususnya pada lahan jagung.

\section{METODE PENELITIAN}

\section{Desain Penelitian}

Penelitian ini merupakan penelitian eksploratif dengan pengujian berskala laboratorium.

\section{Populasi dan Sampel}

Populasi dalam penelitian ini adalah lahan jagung Balai Penelitian Serealia Maros (BALIT-Maros). Sampel berupa tanah kontrol (tanah tanpa perlakuan) dan tanah yang diberi perlakuan. Tanah diberi tiga macam perlakuan, yaitu urea-fosfat-kalium (UPK) polimer zeolit 0\%, UPK polimer zeolit 25\%, dan UPK polimer zeolit 50\%. Poliakrilat yang digunakan merupakan super absorbant polimer (SAP); SAP ini mampu menyerap air hampir 100 kali bobot SAP itu sendiri. Pada penelitian ini, SAP digunakan sebagai control release fertilizer.

\section{Pengumpulan Sampel}

Sampel dikumpulkan dengan cara mengambil tanah sebanyak $\pm 30 \mathrm{~g}$ pada kedalaman $10-15 \mathrm{~cm}$. Kemudian, sampel dimasukkan ke dalam plastik ziplock dan disimpan di lemari pendingin dengan suhu $5^{\circ} \mathrm{C}$ hingga akan digunakan untuk tahap selanjutnya. Sampel disimpan pada suhu ruang sebelum digunakan.

\section{Isolasi Fungi dan Bakteri}

Metode SPC yang digunakan dalam penelitian ini mengacu pada Pepper dan Gerba (2004). Isolasi jamur dan bakteri dimulai dengan pengenceran bertingkat hingga $10^{-5}$. Pada penelitian ini, pengen-ceran yang dikultur pada media nutrient agar (NA) dan potato dextrose agar (PDA) adalah pengenceran $10^{-3}, 10^{-4}$, dan $10^{-5}$. Sampel dikultur menggunakan metode sebar (spread plate), setelah itu, diinkubasi pada suhu $30^{\circ} \mathrm{C}$ selama 2 hari untuk bakteri dan 3 hari untuk fungi.

\section{Isolasi Alga}

Metode MPN yang digunakan dalam penelitian ini mengacu pada Pepper dan Gerba (2004). Isolasi jamur dan bakteri dimulai dengan pengenceran bertingkat hingga $10^{-6}$. Setiap hasil pengenceran $10^{-3}, 10^{-4}, 10^{-5}$, dan $10^{-6}$ diambil sebanyak $0,1 \mathrm{~mL}$ dan ditambahkan ke dalam tabung reaksi berbeda yang berisi $9 \mathrm{~mL}$ larutan Bristol termodifikasi, lalu dihomogenkan menggunakan vorteks. Setiap pengenceran direplikasi 5 kali, setelah itu diinkubasi pada suhu ruang di area terang selama 4 pekan.

\section{Analisis Data}

Jumlah bakteri dan jamur dihitung menggunakan metode standard plate count (SPC), sedangkan alga dihitung menggunakan metode most probable number (MPN).

\section{HASIL DAN PEMBAHASAN}

Tanah merupakan tempat tinggal bagi berbagai jenis organisme termasuk mikroorganisme. Mikroorganisme dalam tanah berperan sangat penting bagi kesuburan tanah. Perannya tidak hanya dalam mentransformasi senyawa kimia tetapi juga sebagai sumber nutrisi dan mineral. Mikroorganisme tanah adalah bagian hidup dari bahan organik tanah. Menurut Oji et al. (2015), mikroorganisme memanfaatkan nutrisi dalam tanah untuk keberlangsungan hidupnya. Mikroorganisme tanah bertanggung jawab melepas nutrisi dari bahan organik yang kemudian digunakan oleh tumbuhan. Mikroorganisme sangat peka akan perubahan yang terjadi di sekitar tanah. Aktivitas budi daya seperti aplikasi pupuk pada tanah dapat berdampak nyata pada keberadaan mikroorganisme tanah (Nakhro \& Dkhar 2010).

Gambar 1 menunjukkan hasil perhitungan bakteri dengan metode SPC. Jumlah sel bakteri yang ditemukan pada tanah kontrol adalah $6.75 \times 10^{4}$ $\mathrm{CFU} / \mathrm{mL}$, pada tanah dengan tambahan UPK polimer zeolit $0 \%$ adalah sekitar $3 \times 10^{4} \mathrm{CFU} / \mathrm{mL}$, dengan tambahan UPK polimer zeolit 25\% meningkat hampir 4 kali lipat. Aplikasi UPK polimer zeolit 50\% bahkan meningkat lebih dari 1000 kali lipat. Jadi, tambahan pupuk anorganik tersebut berpengaruh nyata pada jumlah bakteri tanah.

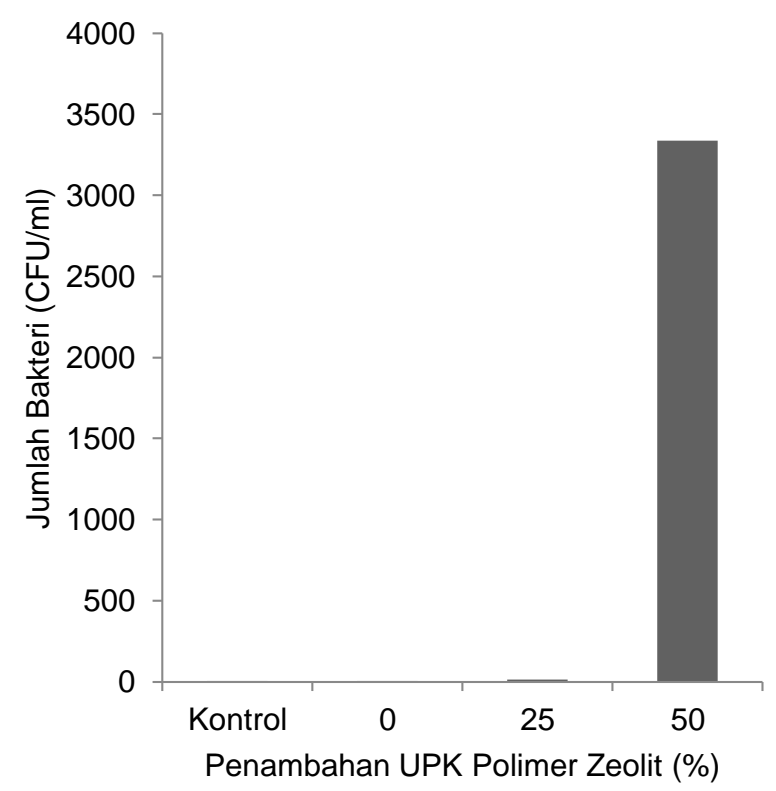

Gambar 1 Rerata jumlah bakteri pada tiga ragam aplikasi urea-fosfat-kalium (UPK) poliakrilat zeolite. 
Hasil perhitungan sel jamur dengan metode SPC ditunjukkan pada Gambar 2. Jumlah sel jamur yang ditemukan pada tanah kontrol adalah 1,00 $\times$ $10^{4} \mathrm{CFU} / \mathrm{mL}$, pada tanah dengan tambahan UPK polimer zeolit yang semakin meningkat adalah berturut-turut $0,35 \times 10^{4}, 2,50 \times 10^{4}$, dan $0,50 \times 10^{4}$ $\mathrm{CFU} / \mathrm{mL}$. Jadi, jumlah sel jamur terbanyak ditemukan pada tanah dengan tambahan UPK polimer zeolit $25 \%$.

Mikroorganisme di dalam tanah memiliki banyak peran, beberapa di antaranya ialah sebagai penyedia unsur hara, perombak bahan organik, dan memacu pertumbuhan tanaman, serta sebagai agen pengendali hama penyakit tanaman. Jumlah populasi mikroorganisme di dalam suatu tanah dapat menjadi indikasi kesuburan tanah tersebut. Hal tersebut adalah karena populasi mikroorganisme yang tinggi menunjukkan keberadaan bahan organik yang cukup, ketersediaan air yang cukup, suhu dan kondisi ekologi tanah yang sesuai (Irfan 2014).

Tumbuhan tidak dapat menyerap zat hara dalam tanah tanpa mikroorganisme yang bekerja dalam tanah. Mikroorganisme memanfaatkan nutrisi pada tanah dan menghasilkan makanan berupa nitrogen, karbon, oksigen, hidrogen, fosforus, kalium, dan mineral lain yang dibutuhkan untuk tumbuh dan memproduksi makanan. Pupuk yang diaplikasikan merangsang pertumbuhan populasi mikroorganisme dengan memasok nutrisi dan kemungkinan memengaruhi individu komunitas mikroorganisme tanah. Mikroorganisme mengubah UPK ke dalam bentuk yang dapat dimanfaatkan oleh tumbuhan untuk tumbuh (Oji et al. 2015), Dari hasil yang didapatkan, terlihat bahwa semakin banyak persentase pupuk yang diaplikasikan semakin banyak jumlah sel bakteri tanah. Akan tetapi pada jamur, hasilnya menujukkan jumlah jamur yang terbanyak adalah pada aplikasi $25 \%$ dan paling sedikit adalah UPK polimer zeolit $0 \%$. Hasil tertinggi ini mungkin disebabkan oleh nitrogen yang

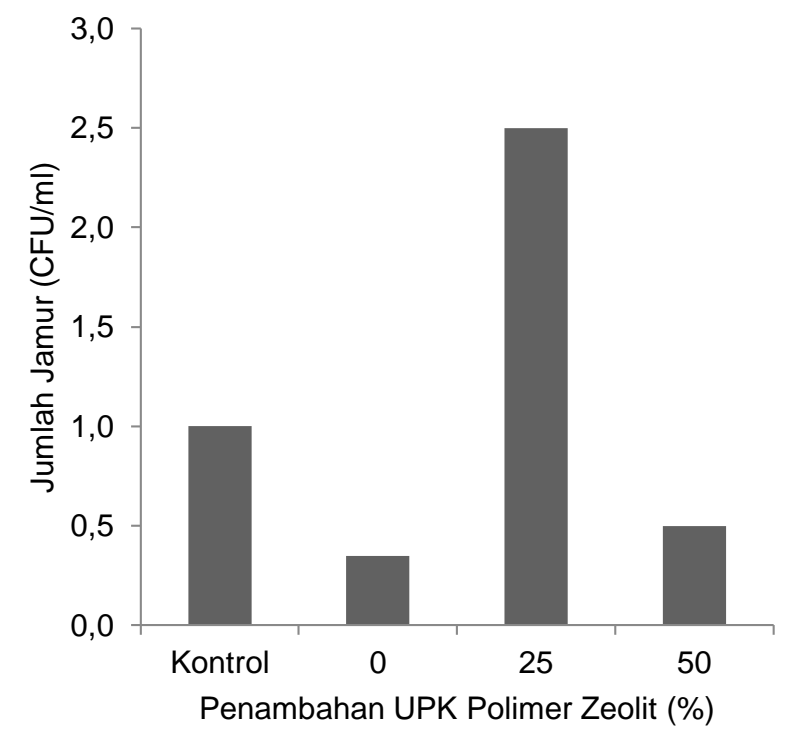

Gambar 2 Rerata jumlah jamur pada tiga ragam aplikasi urea-fosfat-kalium (UPK) poliakrilat zeolite. sangat penting bagi pertumbuhan miselium. Namun, pada aplikasi $50 \%$ jumlah jamurnya lebih sedkit dibandingkan pada aplikasi $25 \%$. Hal ini karena dosis tinggi menurunkan $\mathrm{pH}$ tanah (Baon et al. 2003), sedangkan jamur pada umumnya tumbuh dominan pada $\mathrm{pH}$ rendah dibandingkan bakteri (Mukrin et al. 2019).

Alga sebagian besar adalah kelompok mikroorganisme yang terdiri atas protista fotoautotrofik eukariotik dan sianobakteri prokariotik (kadang-kadang disebut ganggang biru-hijau). Mikroorganisme ini berkontribusi pada setengah dari aktivitas fotosintesis global, terutama alga di lautan. Alga daratan terutama dimiliki oleh tiga silsilah evolusioner yang beragam: alga biru-hijau (sianobakteri), ganggang hijau (klorofita dan streptofita), dan diatom (Bacillariophyceae, okrofita). Secara umum, ditunjukkan bahwa ganggang biru-hijau mewakili komponen utama vegetasi alga daratan di daerah tropis, sedangkan ganggang hijau mewakili unsur dominan di daerah beriklim sedang. Alga hijau adalah salah satu mikroorganisme yang paling umum ditemukan di lingkungan darat. Mayoritas organisme ini melakukan fotosintesis oksigenik di lingkungan terestrial mewakili komunitas yang sangat heterogen dan evolusioner (Singh \& Saxena 2015).

Jumlah sel alga hasil perhitungan sel alga dengan metode MPN yang ditemukan pada tanah kontrol adalah $2,70 \times 10^{4} \mathrm{sel} / \mathrm{g}$ tanah, pada tanah dengan tambahan UPK polimer zeolit dari $0 \%, 25 \%$, dan $50 \%$ berturut-turut adalah $0,02 \times 10^{4}, 0,25 \times 10^{4}$, dan $0,14 \times$ $10^{4} \mathrm{sel} / \mathrm{g}$ tanah. Sebagaimana diperlihatkan pada Gambar 3, jumlah sel alga pada tanah kontrol justru yang terbanyak dibandingkan dengan ketiga perlakuan dengan aplikasi UPK polimer zeolit. Jadi, aplikasi UPK tidak meningkatkan populasi alga tanah. Keberadaan UPK ini seharusnya dapat menjadi sumber energi bagi pertumbuhan alga, seperti dikemukakan oleh Schneider et al. (2018), bahwa keberadaan nutrisi

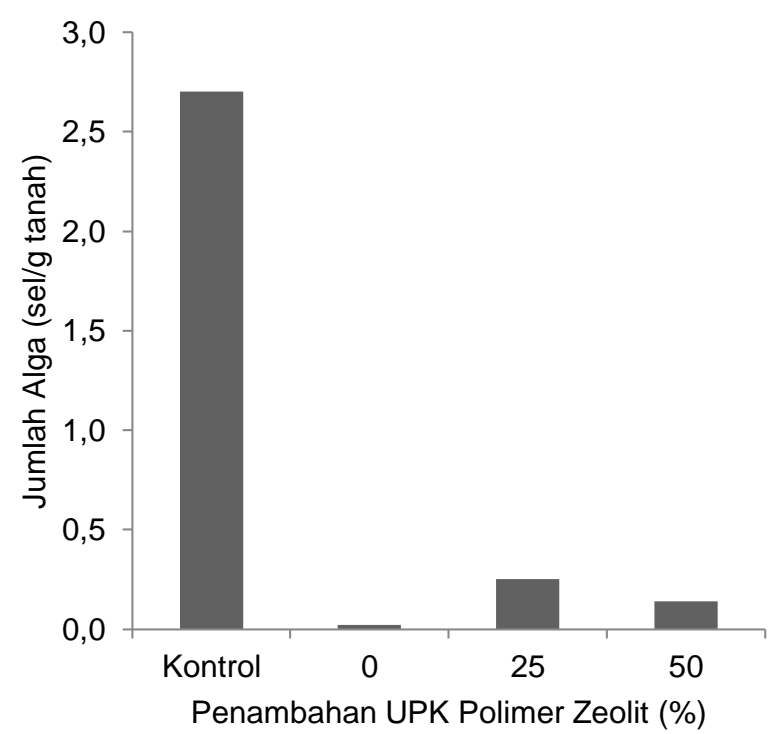

Gambar 3 Rerata jumlah alga pada tiga ragam aplikasi ureafosfat-kalium (UPK) poliakrilat zeolite. 
seperti nitrogen, fosforus, dan unsur lain $(\mathrm{K}, \mathrm{Ca}, \mathrm{Mg}$, $\mathrm{Fe}, \mathrm{Cu}$, dan $\mathrm{Mn}$ ) ini sangat penting untuk metabolisme dan pertumbuhan alga. Hal ini menunjukkan bahwa aplikasi polimer zeolit menghalangi alga dalam memanfaatkan sumber energi dari pupuk UPK.

Polimer zeolit menjadi faktor pelepas lambat urea sehingga alga tidak leluasa menggunakan nutrisi yang terkandung dalam pupuk UPK. Hal ini sesuai dengan yang disampaikan oleh Sofia et al. (2018) bahwa polimer (poliakrilat) zeolit dapat menyebabkan laju pelarutan urea semakin lambat karena penghalang fisik berupa lapisan pelindung pada urea. Zeolit juga menyebabkan proses perubahan ion amonium menjadi ion nitrat melambat. Zeolit memiliki rongga dengan ukuran yang sesuai dengan ukuran ion amonium. Jika konsentrasi ion amunium di dalam tanah relatif tinggi, maka ion amonium yang terserap ke dalam pori-pori zeolit tidak akan terlepas ke dalam tanah. Ion amonium baru akan terlepas setelah berubah menjadi nitrat.

\section{KESIMPULAN}

Aplikasi pupuk UPK polimer zeolit berpengaruh nyata pada meningkatnya jumlah bakteri dan jamur pada tanah tetapi tidak untuk populasi alga. Penelitian ini hanya berfokus pada jumlah mikroorganisme pada tanah di lahan jagung, sehingga tidak diketahui pengaruh kelimpahan mikroorganisme ini pada pertumbuhan jagung. Oleh karena itu, perlu dilakukan penelitian lebih lanjut mengenai pengaruh kelimpahan mikroorganisme tanah pada pertumbuhan tanaman jagung.

\section{DAFTAR PUSTAKA}

Baon JB, Inayah F, Suhartono B, Winarso S. 2003. Efisiensi Pemupukan Nitrogen, Sifat Kimiawi Tanah dan Pertumbuhan Kakao Akibat Dosis dan Ukuran Zeolit. Pelita Perkebunan. 19(3): 126-139.

Dalal RC. 1998. Soil microbial biomass-what do the numbers really mean? Australian Journal of Experimental Agriculture. 38(7): 649-665. https://doi.org/10.1071/EA97142

Irfan M. 2014. Isolasi dan enumerasi bakteri tanah gambut di perkebunan kelapa sawit PT. Tambang Hijau Kecamatan Tambang Kabupaten Kampar. Jurnal Agroteknologi. 5(1): 1-8.

Kay-Shoemake JL, Watwood ME, Lentz RD, Sojka RE. 1998. Polyacrylamide as an organic nitrogen source for soil microorganisms with potential effects on inorganic soil nitrogen in agricultural soil. Soil
Biology and Biochemistry. 30(8-9): 1045-1052. https://doi.org/10.1016/S0038-0717(97)00250-2

Li FH, Wang AP. 2016. Interaction effects of polyacrylamide application and slope gradient on potassium and nitrogen losses under simulated rainfall. Catena. 136: 162-174. https://doi.org/ 10.1016/j.catena.2015.05.008

Mukrin, Yusran, Toknok B. 2019. Populasi Jamur dan Bakteri Tanah pada Lahan Agroforestri dan Kebun Campuran di Ngata Katuvua Dongi-dongi Kecamatan Palolo Kabupaten Sigi Sulawesi Tengah. Journal of Forest Sains. 16(2): 77-84.

Nakhro D, Dkhar MS. 2010. Impact of Organic Fertilizers on Microbial Population and Biomass Carbon in Paddy Field Soil. Journal of Agronomy. 9(3): 102-110. https://doi.org/10.3923/ja.2010. 102.110

Oji, Oi, Olajire-Ajayi BL, Dada OV, Wahab OM. 2015. Effects of fertilizers on Soil's Microbial Growth and Population: A Review. American Journal of Engineering Research. 4(7): 52-61.

Pepper, I.L. \& Gerba, C.P. 2004. Environmental microbiology: a laboratory manual. London: Elsevier academic press.

Schneider RCS, Lima MM, Hoeltz M, Neves FF, John DK, de Azevedo A. 2018. Life cycle assessment of microalgae production in a raceway pond with alternative culture media. Algal Research. 32: 280292. https://doi.org/10.1016/j.algal.2018.04.012

Singh J, Saxena RC. 2015. An Introduction to Microalgae. Handbook of Marine Microalg.11-24. https://doi.org/10.1016/B978-0-12-800776-1.00 002-9

Sofia ARB, Oslan J, Hilda K. 2018. Pengaruh pemberian pupuk urea dengan polimer poliakrilat, zeolit dan mimba (Azadirachta indica) terhadap pertumbuhan tanaman jagung. Jurnal Bionature. 19(1): 35-46.

Yenni A, Suherman, Purbasari A. 2012. Pembuatan Slow-Release Fertilizer Dengan Menggunakan Polimer Amilum dan Asam Akrilat Serta Polivinil Alkohol Sebagai Pelapis Dengan Menggunakan Metoda Fluidizedbed. In: Prosiding Seminar Nasional Sains dan Teknologi Ke-3 Tahun 2012, Fakultas Teknik Universitas Wahid Hasyim Semarang. Semarang (ID): Juli 2012. 